\title{
ENZYMATIC HYDROLYSIS OF SUGARCANE BAGASSE IN ROTATING DRUM REACTOR
}

\author{
P. A. S. Monteiro ${ }^{1}$, P. Seleghim Jr. ${ }^{1}$ \\ ${ }^{1}$ University of São Paulo, Engineering School of São Carlos, Mechanical Engineering \\ Department, São Paulo, Brazil \\ pamarasantiago@gmail.com
}

\begin{abstract}
In the last 15 years researches have aimed a more efficient use of agroindustrial residues for the production of fuels such as ethanol obtained from sugarcane bagasse. However, in this case, the production in large scale using this raw material is still unfeasible. One of the reasons for this unfeasibility is the knowledge required for the development of hydrolysis step due to reaction complexity and high cost of enzymes. In order to enhance this step, the use of reactor can create an environment that allows a maximum conversion of cellulose with a minimum quantity of enzymes. Thus, the aim of this work is to use a rotating drum reactor able to process a large amount of biomass. However, at high solid loadings of this substrate, the viscosity of the medium will be very high and other factors should also be considered, such as mixing, mass and heat transfer limitations. The present paper deals with the analysis of the enzymatic hydrolysis process of sugarcane bagasse performed in rotating drum reactor (working volume of $4 \mathrm{~L}$ ), using bagasse $(10 \mathrm{w} / \mathrm{v})$ and commercial cellulase enzyme. In this study sugarcane bagasse was submitted, firstly, chemical pretreatment that consisted of two consecutive steps, the first with dilute sulfuric acid $\left(1 \% \mathrm{H}_{2} \mathrm{SO}_{4}\right)$, and the second with alkaline solution of $\mathrm{NaOH}(1 \%)$. Hydrolyses were performed with an enzyme load of 7 and 15 FPU/g (dry weight) of bagasse with periodic sampling for the measurement of the concentration of glucose. The results of the experiments showed an increase in the glucose concentration $\left(\mathrm{g} \mathrm{L}^{-1}\right)$ due to the mass transfer and mixing allowing a larger contact area of the enzyme with the substrate (sugarcane bagasse) in the reactor.
\end{abstract}

\section{INTRODUCTION}

Currently, the international energy system is very dependent on fossil fuels (coal, oil and gas), since about $80 \%$ of a global energy consumption is originated from these sources. This is a situation that deserves to change, not only by the gradual depletion of fossil fuel reservoir, as well as negative effects on the environmental that result from their use, as global warming (Ogeda and Petri, 2010). The emissions of $\mathrm{CO}_{2}$ in the atmosphere are being viewed responsible for causing extensive climate changes (Buckeridge et al., 2009).

The search for alternative fuels has made some countries to choose biofuels due to the renewable nature, low cost and local availability of lignocellulosic biomass. An example of these biofuels is ethanol produced by fermentation of sugars (first generation ethanol) extracted primarily from sugarcane sugar, corn, sugar beet, among other sources. (Ogeda and Petri, 2010). Another route for ethanol production is by the use of cellulosic biomass. In the 
last year, this possibility of obtaining fuel has resulted in large investments in the biofuel industry.

In order to produce ethanol from cellulosic biomass it's necessary to go through 5 steps of processing namely, pretreatment, (enzymatic) hydrolysis, fermentation, product separation, and post-treatment of the liquid fraction (Bansal et al., 2009; Ogeda and Petri, 2010). The development of technology for enzymatic hydrolysis is an important parameter to the conversion of lignocellulosic biomass to biofuel yield (Bansal et al., 2009; Soccol et al., 2010; Pereira et al., 2011). Although the chemical hydrolysis of biomass from sugarcane is a consolidated method under laboratory conditions (Soccol et al., 2010), the advantages of the enzymatic hydrolysis of cellulose over the chemical methods for energy consumption as it operates under mild temperature, $\mathrm{pH}$, and pressure conditions (Sun and Cheng, 2002; Pereira et al., 2011).

Wang et al. (2011) observed a decrease of conversion of cellulose to high substrate concentration, and concluded that this does not occurred neither due to loss of enzyme activity nor inhibition of the final product. Instead, the authors linked this result with the change of a capacity of adsorption of the enzyme in higher solids loading. The lower binding capacity of cellulase is possible to lead to a lower surface coverage of enzyme on cellulose, thus may influence the hydrolysis of cellulose. Instead, it may be related to the change of adsorption capacity at high solid loading. The authors did not discard the influence of other factors, such as the slower three-dimensional diffusion of enzymes in solution, and some substances in enzyme solution maybe also related to the decreased sugar yield. Cellulase adsorption to cellulose has been thought to be much related to the hydrolysis of cellulose, and the results showed that more studies are needed to better understand the mechanism of adsorption of enzyme on cellulose.

Pereira et al. (2011) investigated the enzymatic hydrolysis in a bioreactor type STR (mechanically stirred), capacity of 1 L, (Model Biostat B-plus, Sartorius) equipped with turbine impeller. In this study, the sugarcane bagasse and enzyme concentration was $0.1 \mathrm{Kg} . \mathrm{L}^{-}$ ${ }^{1}$ and 10 FPU.g ${ }^{-1}$ dry bagasse (Trichoderma reesei RUT C30 and Aspergillus awamori 2B.361 $\mathrm{U} 2 / 1$ ), respectively. The authors obtained a releasing of glucose of $27 \mathrm{~g} . \mathrm{L}^{-1}$ in 40 hours, and this value was lower than that those obtained in the present study with the bioreactor.

O'Dwyer et al. (2006) performed the experiments using enzymatic hydrolysis corn stover and different concentrations of enzymes (Trichoderma reesei - from 0.25 to $50 \mathrm{FPU} \mathrm{\textrm {g } ^ { - }}$ ${ }^{1}$ dry straw). Glucose has a binding affinity equal to the enzyme that may cause the cellulose inhibit for the glucose enzyme bond. Another explanation is not presented for the preference and irreversible binding of lignin. Data obtained ranged from 10 to 100 g.L $\mathrm{L}^{-1}$ in $72 \mathrm{~h}$.

The aim of the present study was to evaluate the performance of a rotating drum reactor (RDBs) in the enzymatic hydrolysis of sugarcane bagasse. This type of equipment has a potential to provide better heat and mass transfer than solid state fermentation (SSF) bioreactors with static beds, and a gentle agitation when compared to the mechanically stirred bioreactors. The gentle agitation associated with the tumbling motion of the substrate bed minimizes the damage to the substrate particles (Hardin et al., 2002). Furthermore, the 
absence of internal moving parts for mixing makes a simpler design, construction and operation.

\section{MATERIAL AND METHODS}

\subsection{Substrates}

Sugarcane bagasse samples used in the experiments were provided by Raizen Group (São Paulo State, Brazil) are from the harvest (2011/2012) and provided by. Prior to pretreatment and analysis the sugarcane bagasse samples were dried at $45{ }^{\circ} \mathrm{C}$ for $48 \mathrm{~h}$ and stored in plastic containers at room temperature until to be used (Rabelo, 2010).

\subsection{Enzyme Hydrolysis}

The sugarcane bagasse was initially treated in acid at 1:16 to solubilize hemicelluloses (1 gram of dry bagasse was treated in $16 \mathrm{ml}$ of $1 \% \mathrm{H}_{2} \mathrm{SO}_{4}$ solution). After this, the samples were treated with alkaline solutions of $1 \% \mathrm{NaOH}(\mathrm{v} / \mathrm{v})$ to promote the delignification. The suspension containing sugarcane bagasse was autoclaved for $40 \mathrm{~min}$ at $1 \mathrm{~atm}$ and $120^{\circ} \mathrm{C}$. In the following, the samples were abundantly washed with distilled water to eliminate acid or alkaline excesses until a neutral $\mathrm{pH}$ and solid were dried in an oven for more 24 hours at $60^{\circ} \mathrm{C}$ (Rezende et al., 2011). The determination of the carbohydrate content of the pretreated bagasse samples was done through Thermal Analysis (TG/ DTG and DTA) (Cruz et al., 2013).

Enzymatic hydrolysis experiments were performed in Erlenmeyer flask (control) and in the reactor. The experiments in Erlenmeyer flasks were carried out using $0.1 \mathrm{Kg}$ (dry weight) $\mathrm{L}^{-1}$ of pretreated sugarcane bagasse an enzyme load (Accellerase $1500^{\circledR}$ cellulose enzyme Danisco, Rochester, NY, USA) of 7 and 10 FPU.g $^{-1}$ dry biomass. The suspensions were incubated at $200 \mathrm{rpm}, 323.15 \mathrm{~K}$ and $\mathrm{pH} 4.8$ (sodium citrate buffer, $50 \mathrm{mM}$ ).

The experiments in the rotating drum reactor were performed at a concentration of 100 g. $\mathrm{L}^{-1}$ bagasse, corresponding to $10 \% \mathrm{w} / \mathrm{v}$ filling degree. In the reactor, the suspensions were incubated at $15 \mathrm{rpm}, 50{ }^{\circ} \mathrm{C}$ and $\mathrm{pH} 4.8$ (sodium citrate buffer, $50 \mathrm{mM}$ ) for $72 \mathrm{~h}$.

During hydrolysis process, both on the reactor and Erlenmeyer flasks, the samples were collected at times of 2, 4, 6, 24, 48 and $72 \mathrm{~h}$ and inactivated by increasing the temperature to $80^{\circ} \mathrm{C}$ for $15 \mathrm{~min}$. Glucose concentration was determined using a kit based on the glucose oxidase reaction (reagent GOD PAD). Cellulase activity was measured by the filter paper method as described by Ghose (Ghose, 1987) and it corresponds to 25 FPU.mL ${ }^{-1}$.

\subsection{Equipment - Rotating drum reactor}

The rotating drum reactor employed on the experiments was made of stainless steel with a diameter of $0.45 \mathrm{~m}$, a length of $0.25 \mathrm{~m}$ and a total internal volume of $0.038 \mathrm{~m}^{3}$ (Salles, 2013). In order to improve the mixture, four straight baffles were longitudinally installed to stir the bagasse. Outside the inner cylinder a heat exchanger was installed and it is responsible for maintaining the temperature of the reaction media in $50^{\circ} \mathrm{C}$. The reactor also presents 
temperature sensors installed outside the drum (Figure 1). The working volume was of $10 \%$ of the total equipment capacity.

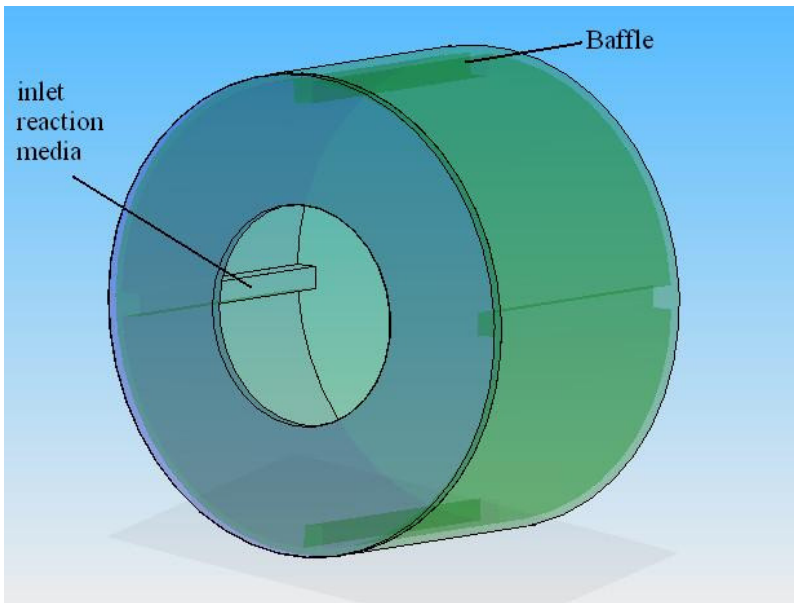

Figure 1. Schematic representation of the rotating drum reactor.

\subsection{Fundamental calculations of rotating drum reactor}

The rotating drum reactors consist of a horizontal rotating cylinder to around its axis. The mixing occurs by a tumbling motion of the solid substrate, aided by baffles on the inner wall of the rotating drum. Rotation can be intermittent or continuous, depending on the importance of mixing effects on the solid substrate (Wang et al., 2010).

This type of equipment has attracted interest because it provides a gentle stirring in bed. Hardin et al. (2002) studied the dynamics of mixing in these bioreactors and cited three basic forms of the transverse bed motion, which occurrence dependent of the speed of rotation of the cylinder. These forms are: slipping motion, cascading tumbling. motion and cataracting motion. In applications of rotating drums, the radial flow regime within the solid bed is important because it affects the heat and mass transfer between the bed and the headspace and the homogeneity within the bed (Wang et al., 2010).

To delimit the types of bed motion, the ranges for Froude number and filling degree are specified. The Froude number (Fr) represents ratio of centrifugal force to gravity. The centrifugal force is related to the inner radius of the cylinder, hence this criterion is also named the peripheral Froude number and calculated from Equation 1.

$$
\operatorname{Fr}=\frac{\omega^{2} R}{g}
$$

where $\omega$ - drum angular velocity, $\mathrm{R}$ - radius of the drum; $\mathrm{g}$ - gravity acceleration.

The angular velocity $(\omega)$ is calculated by the frequency or rotational velocity $(\mathrm{F})$, as in Equation 2.

$$
\omega=2 \pi F
$$


The degree of filling, as the portion of the cylinder cross-section occupied by the bed, is determined by the filling angle, as in Equation 3.

$$
f=\frac{1}{\pi}(\varepsilon-\sin \varepsilon \cos \varepsilon)
$$

The filling angle corresponds to the half bed angle of the circular segment occupied with solids. Assuming a flat bed surface, its distance from the axis of rotation is calculated from $r_{0}=R \cos \varepsilon$. Thus, the width (chord) of the solid bed is given by $S=2 R \sin \varepsilon^{\prime}$ and the maximum bed depth at mid-chord amounts to $h=R-r_{o}$ (Mellmann, 2001).

Thus, the operating conditions of the reactor ( $15 \mathrm{rpm}$ rotation speed), the value of filling degree was 0.23 and the Froude number was $\mathrm{Fr}=5.6 \times 10^{-2}$. Based on these values, characterized the regime of solids inside the equipment, which was: Cascading and the subform was cascading. For this type of motion (Cascading), the height of the arch bed increases with increasing in rotational speed. The sub-form cascading characterized by an arcuate surface and higher particle velocities present in free surface and also a flow regime that promotes good mixing of solids. According Xavier et al. (2009), this sub-form is predominant in reactors rotary drum.

In order to better characterize the mixture inside the reactor was determined the critical rotational $\left(\mathrm{N}_{\mathrm{C}}\right)$, which is defined as the speed at which the particles are held against the inside of the drum wall by centrifugal action. This is a function of the drum diameter and for a horizontal drum is given by Equation 4 (Mitchell et al., 2006).

$$
N_{C}=\frac{42}{\sqrt{D}}
$$

where $\mathrm{N}_{\mathrm{C}}$ is in rpm and $\mathrm{D}$ is the drum diameter.

In this work, $\mathrm{N}_{\mathrm{c}}$ was $62 \mathrm{rpm}$ for the conditions applied in this study. As the speed of rotation of the drum was $15 \mathrm{rpm}$, this means $25 \%$ of the critical value, firstly a rolling flow characterized by a flat surface, and consequently a cascading flow characterized by a curved surface. It was observed that there were no particles in suspension.

\section{RESULTS AND DISCUSSION}

Untreated bagasse has 35\% cellulose and amounts of hemicellulose (25\%) and lignin (22\%). The cellulose amount increased continuously after pretreatment, ranging from an initial $35 \%$ content to circa $75 \%$ under pretreatments using $\mathrm{NaOH} 1 \%$. Thus, the final composition sugarcane bagasse was: cellulose $75.0 \%$; hemicellulose $3.5 \%$; lignin $17.1 \%$ and ashes $4.4 \%$ (Cruz et al., 2013). After the pre-treatment, the pulp was added in the reactor for the purpose to start the process of hydrolysis.

Figure 2 shows the results of experiments performed in Erlenmeyer flasks (control) and reactor. 


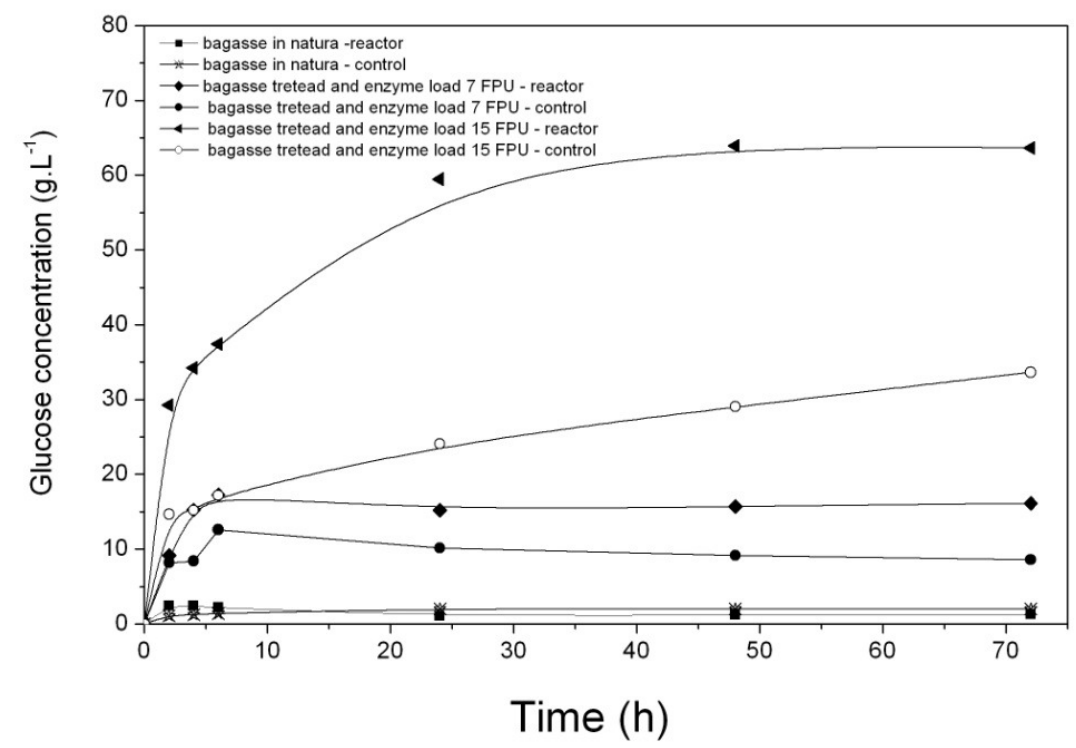

Figure 2. Results of the experiments of hydrolysis of sugarcane bagasse, untreated and pretreated, performed in Erlenmeyer flasks and rotating drum reactor, varying the enzyme concentration.

Through the Figure 2, it can be seen that in all the experiments, the process of cellulose hydrolysis was completed in 24 hours. After this period, there was little variation in the amount of glucose produced. This occurred, in the case of biomass without pretreatment because the enzyme did not have access to the substrate. In other cases, the pretreated biomass, the enzyme concentration was insufficient (for example in experiments with enzyme concentration (7 FPU.mL ${ }^{-1}$ ) or due to problems related to product inhibition.

After the experiments with biomass without pretreatment, it was conducted tests with a minimum concentration of enzyme or 7 FPU.mL ${ }^{-1}$. According Sun and Cheng (2002) the range of concentration of enzyme used in the process varied 7 to 33 FPU.mL ${ }^{-1}$. Therefore, in this work, the experiments were performed in Erlenmeyer flasks and in the reactor with enzyme concentration of 7 FPU.g ${ }^{-1}$ dry bagasse.

Santos and Gouveia (2009) observed in experiments with sugarcane bagasse pretreated, with concentration of $186.16 \mathrm{~g} . \mathrm{L}^{-1}$ in bottles flasks using a enzyme concentration of 17.2 FPU $\mathrm{g}^{-1}$ dry bagasse (Celluclast 1500 ), that after 46 hours, the process stabilized. To solve this problem, it was added more $2.10^{-3} \mathrm{~L}$ of enzyme in the process, an attempt, to increase the conversion of the enzyme. However, there was not process improvement, the authors attributed this to the presence of lignin in the reaction medium, which results in a slow conversion and a high glucose concentration and inhibits the action of beta-glycosidase enzymes. For the reduction of these effects of inhibition during hydrolysis, some procedures have been suggested by Sun and Cheng (2002), as the removing sugars (glucose) during hydrolysis semi-continuous process or by ultrafiltration of the reaction medium.

Due to the low levels of glucose concentration obtained in the experiment at a concentration of enzyme 7 FPU.g ${ }^{-1}$ dry bagasse it was decided to increase the amount of enzyme load to 15 FPU.g ${ }^{-1}$ dry bagasse. The increase in enzyme concentration also caused an increase in the concentration of glucose. Based on the initial concentration of dry bagasse 
$\left(100\right.$ g. $\left.\mathrm{L}^{-1}\right)$, the final glucose concentration was approximately 63 g. $\mathrm{L}^{-1}$, a conversion of $84 \%$. In function of the bioreactor, the yield was much higher due to a better mass transfer and heat, and a mixture inside the equipment in relation to the Erlenmeyer flasks. There was no significant change in the results in both experiments after 24 hours of cultivation, showing that the hydrolysis process stabilized. One possible factor for this occurrence is the product inhibition (glucose).

\section{CONCLUSIONS}

In the experiments performed in the reactor was observed that the results of conversion of cellulose to glucose were higher than the control, due to better mixing of the reaction medium, and hence greater access to the enzyme to substrate. The reactor was adequate to be used in the process of hydrolysis

\section{ACKNOWLEDGEMENTS}

The authors gratefully acknowledge CAPES (DS00011/07-0), CNPq, and FAPESP for the financial support of the research (Proc. 2010/20681-4), Thermal Engineering and Fluids Laboratory (NETeF) from University of São Paulo (USP) and the DuPont Company for donating the enzyme (Accellerase $1500^{\circledR}$ ).

\section{REFERENCES}

BANSAL, P; HALL, M.; REALFF, M.J; LEE, J.H; BOMMARIUS, A.S. Modeling cellulase kinetics on lignocellulosic substrates. Biotechnol. Adv., v. 27, p. 833-848, 2009.

CRUZ, G.; MONTEIRO, P.A.S; BRAZ, C.E.M.; SELEGHIM JR., P; POLIKARPOV, I. CRNKOVIC, P.M. Thermal and morphological evaluation of chemically pretreated sugarcane bagasse, In: World Academy of Science, Engineering and Technology (WASET), 2013, Paris. World Academy of Science, Engineering and Technology (WASET). Paris, 2013. v. XVII. p. 2179-2184, 2013.

GALBE M.; ZACCHI G. A review of the production of ethanol from softwood. Appl. Microb. Biotechnol. v. 59, p. 618-28, 2002.

GAN, Q.; ALLEN, S.J.; TAYLOR, G. Kinetic dynamics in heterogeneous enzymatic hydrolysis of cellulose: an overview, an experimental study and mathematical modeling. Process Biochem., v. 38, p. 1003-1018, 2003.

GHOSE, T. K. Pure and Applied Chemistry. J. Chemical Physics, v. 59 (2), p. 257-268, 1987.

GRAJALES, L.M.; XAVIER, N.M; HENRIQUE, J.P; THOMÉO, J.C. Mixing and motion of rice particles in a rotating drum. Powder Technol., v. 222, p. 167-175, 2012.HARDIN, M; HOWES, T; MITCHELL, D. Mass transfer correlations for rotating drum bioreactors. $J$. Biotechnol., v. 97, p. 89 - 101, 2002.

LYND, L.R; LASER, M.S; BRANSBY, D; DALE, B.E; DAVISON, B; HAMILTON, R. How biotech can transform biofuels. Nature Biotechnol. , v. 26, p. 169-72, 2008.

MELLMANN, J. The transverse motion of solids in rotating cylinders-forms of motion and transition behavior. Powder Technol., v. 118, p. 251-270, 2001.OGEDA, T.L.; PETRI, 
D.F.S. Hidrólise enzimática de biomassa. São Paulo: Quím. Nova, v. 33 (7), p. 1549-1558, 2010.

MITCHELL, D.A.; STUART, D.M.; HARDIN, M.T.; KRIEGER, N. Rotating-Drum and Stirred-Drum Bioreactors. In: Solid-State Fermentation Bioreactors - Fundamentals of design and operation. Berlin: Springer-Verlag cap.8, 2006.

OGEDA, T.L.; PETRI, D.F.S. Hidrólise enzimática de biomassa. São Paulo: Quím. Nova, v.33 (7), p. 1549-1558, 2010.

O'DWYER J.P.; ZHU, L.; GRANDA C.B.; HOLTZAPPLE M.T. Enzymatic hydrolysis of lime-pretreated corn stover and investigation of the $\mathrm{HCH}-1$ Model: Inhibition pattern, degree of inhibition, validity of simplified HCH-1 Model. Bioresource, v. 98, p. 29692977, 2006.

PEREIRA, L.T.C.; TEIXEIRA, R.S.S.; BON, E.P.S.; FREITAS, S.P. Sugarcane bagasse enzymatic hydrolysis: rheological data as criteria for impeller selection. J. Ind. Microbiol. Biotechnol., v. 38, p. 901-907, 2011.

RABELO, S. Avaliação e otimização de pré-tratamentos e hidrólise enzimática do bagaço de cana-de-açúcar para a produção de etanol de segunda geração. (in Portuguese). Tese Doutorado - Unicamp. (2010).

REZENDE, C.A.; LIMA, M.A.; MAZIEIRO, E.R.; AZEVEDO, E.R.; GARCIA, W.; POLIKARPOV, I. Chemical and morphological characterization of sugarcane bagasse submitted to a delignification process for enhanced enzymatic digestibility. Biotechnol. Biofuels, v. 4 (54), p. 1-19, 2011.

SALLES, P. Avaliação de um reator tipo tambor rotativo para hidrólise enzimática do bagaço de cana-de-açúcar. Dissertação Mestrado (in Portuguese). Escola de Engenharia de São Carlos. Departamento de Engenharia Mecânica. (2013).

SOCCOL C. R.; VANDENBERGHE L.P.S.; MEDEIROS A.B.P.; KARP S.G.; BUCKERIDGE M.; RAMOS L.P.; PITARELO A.; FERREIRA-LEITÃO V.; GOTTSCHALK L. M.F.; FERRARA M.A.; BON E. P.S.; de MORAES L. M.P.; ARAÚJO J.A.; TORRES F.A.G. Bioethanol from lignocelluloses: Status and perspectives in Brazil. Bioresour. Technol. v. 101, p. 4820-4825, 2010.

SANTOS, J.R.A.; GOUVEIA, E.R. Produção de bioetanol de bagaço de cana-de-açúcar. Revista Brasileira de Produtos Agroindustriais, Campina Grande 11 (2009) 27-33.

SUN, Y.; CHENG, J. Hydrolysis of lignocellulosic materials for ethanol production: a review. Bioresour. Technol. v. 83, p. 1-11, 2002.

XAVIER, N.M; GRAJALES, L.M.; THOMÉO, J.C. (2009). "Características de movimentação e mistura de partículas de um biorreator rotativo para fermentação em estado sólido" (in Portuguese). VIII Congresso Brasileira de Engenharia Química em Iniciação Científica. (2009). Uberlândia, Brazil.

WANG, E.; LI, S.; TAO, L. GENG, X. LI T. Modeling of rotating drum bioreactor for anaerobic solid-state fermentation. Appl. Energy, v. 87, p. 2839-2845, 2010.

WANG et al. Study on the decreased sugar yield in enzymatic hydrolysis of cellulosic substrate at high solid loading. Appl. Biochem. Biotechnol., v. 164, p. 1139-1149, 2011. 